\title{
Combined Use of Cyanoditolyl Tetrazolium Staining and Flow Cytometry for Detection of Metabolically Active Bacteria in a Fed-batch Composting Process
}

\author{
YASUYUKI FUJII ${ }^{1}$, and AKIRA HIRAISHI ${ }^{1 *}$ \\ ${ }^{1}$ Department of Ecological Engineering, Toyohashi University of Technology, Tempaku-cho, Toyohashi 441-8580, Japan
}

(Received October 23, 2008-Accepted January 6, 2009—Published online January 29, 2009)

Microbial community dynamics with metabolically active bacteria during the start-up operation of a personal fedbatch composting (FBC) reactor were studied. The FBC reactor was loaded daily with household garbage for 2 months. Metabolically active bacteria were monitored by the redox-dye-staining method using 5-cyano-2,3-ditoryl tetrazolium chloride (CTC), and the fluorescent formazans thus produced were detected by epifluorescence microscopy and flow cytometry (FCM). Microscopic CTC-positive (CTC+) counts accounted for 75-84\% of the direct total count during the first week of operation and 19-35\% thereafter. Slightly higher CTC+ counts were obtained by FCM. Culture-independent approaches by quinone profiling and denaturing gradient gel electrophoresis (DGGE) of PCRamplified 16S rRNA genes showed that a drastic population change from ubiquinone-containing members of the Proteobacteria to the Actinobacteria took place during the overall period of operation. The PCR-DGGE analysis of FCM-sorted CTC+ cells supported this observation but gave different major clones from those detected in the total community in some cases. These results suggest that metabolically active bacteria as measured by CTC staining are not always predominant in the FBC process.

Key words: fed-batch composting, tetrazolium reduction, flow cytometry, microbial community

The fed-batch composting (FBC) process not only has great promise for practical use in waste treatment technology but also provides a good model of microbial ecology in terms of microbial population dynamics during the biodegradation of solid organic substances. In general, this process uses relatively small-scale reactors which are loaded repeatedly with biowaste without removal of treated material during an appropriate period of operation. Therefore, FBC reactors have a lower and narrower range of temperature depending upon self-heating than the traditional single-batch composting system (24), which has three to four different thermal stages $(11,43)$. This characteristic feature of the FBC process may be responsible for particular microbial community dynamics different from those for the conventional composting system.

Previous studies on mesophilic FBC reactors for garbage treatment have shown that a population shift from members of the phylum Proteobacteria to those of the phylum Actinobacteria takes place during a start-up period of operation (17, $23,25,41)$. Moisture or water activity $\left(a_{\mathrm{w}}\right)$ may be one of the most important determinants of this population shift $(25,41)$. However, major questions to be answered are whether the predominant bacteria in the FBC process are always metabolically active and what kinds of microorganisms are actually responsible for the degradation of household organic waste. Although high culturability of microorganisms in FBC reactors provides circumstantial evidence for high proportions of viable bacteria $(17,26)$, there has been only fragmentary information about relationships between the predominant bacteria and metabolically active bacteria during the FBC treatment of garbage.

One of the most promising methods for the detection

\footnotetext{
* Corresponding author. E-mail: hiraishi@eco.tut.ac.jp; Tel: +81532-44-6913; Fax: +81-532-44-6929.
}

of metabolically active microorganisms is the tetrazolium reduction assay using 5-cyano-2,3-ditoryl tetrazolium chloride (CTC), which can quantify the activity of dehydrogenases. CTC is converted to a red fluorescent formazan as the result of reduction, and CTC-positive $(\mathrm{CTC}+)$ bacteria can be detected at a single cell resolution by epifluorescence microscopy $(5,7,9,14,30-32,37,39,44,48)$, confocal laser scanning microscopy (12), and flow cytometry (FCM) $(4,8$, $13,21,38,40,46)$. The main purpose of this study was therefore to elucidate relationships between the predominant bacteria and metabolically active bacteria in the FBC process by using the CTC staining technique, with both epilfluorescence microscopy and FCM used for detection. Attempts to phylogenetically identify CTC + bacteria by FCM sorting and denaturing gradient gel electrophoresis (DGGE) of PCRamplified 16S rRNA genes were also made.

\section{Materials and Methods \\ Operation of reactors}

A commercial personal composter, a SANYO model SMS-K2 (Sanyo Electric Co., Moriguchi, Japan), was used as the FBC reactor. The reactor has a working capacity of $33 \mathrm{~L}$ and contained $18 \mathrm{~L}$ of fresh wood chips (Sanyo) as the solid matrix at the start of operation. The organic waste used for composting was collected daily from a restaurant of Toyohashi University of Technology. Detailed information about the reactor and the biowaste has been given previously $(23,26)$. The organic wastes were cut into pieces of less than $3 \mathrm{~cm}$ square if needed, and added manually to the reactor. The reactor was operated for 2 months with a $24 \mathrm{~h}$-fed-batch cycle at a waste-loading rate of $0.7 \mathrm{~kg}$ (wet wt) day ${ }^{-1}$. Every hour in a batch cycle and just after waste addition, an impeller in the reactor automatically rotated to mix the solid waste-compost mixture (SCM) for $5 \mathrm{~min}$, and this was the only way to aerate SCM. During the overall period of operation, the reactor was kept in an incubator room at $22^{\circ} \mathrm{C}$ and $50 \%$ humidity. 


\section{Sample collection and physico-chemical analyses}

SCM samples ( $5 \mathrm{~g}$ wet weight each) were collected from at least three different points of the core of the reactor at the end of each batch cycle on days $1,3,5,7,14,21,28,42$, and 56 . Before sampling, the SCM was stirred and mixed well with a scoop. Collected samples were combined and screened by stainless steel sieve with a $5 \mathrm{~mm}$ mesh to remove large debris. Then, the samples were immediately subjected to physicochemical and microbiological analyses, whereas those for the quinone analysis were stored at $-30^{\circ} \mathrm{C}$ until used. The mass reduction rate, moisture content, $\mathrm{pH}$, core temperature, and conductivity were measured as described previously (41). Water activity was measured using an AW SPRINT HT-500 water activity analyzer (Novasina, Switzerland) according to the manufacturer's instructions.

\section{Quinone analysis}

Quinones were extracted from SCM samples with an organic solvent mixture and separated into menaquinone and ubiquinone fractions using Sep-Pak Vac silica gel cartridges (Waters, Milford, MA, USA). The quinone components of each fraction were quantified and identified by reverse-phase HPLC and photodiode array detection with external standards. Detailed information on these analytical procedures has been given previously $(15,16)$. Ubiquinones and menaquinones with $n$ isoprene units in their side chain were abbreviated as Q- $n$ and MK- $n$, respectively. Partially hydrogenated menaquinones were expressed as MK- $n\left(\mathrm{H}_{x}\right)$, where $x$ indicates the number of hydrogen atoms saturating the side chain.

\section{Direct cell counting}

For cell counting, $1 \mathrm{~g}$ (wet wt) of SCM sample was suspended in $9 \mathrm{~mL}$ of filter-sterilized $50 \mathrm{mM}$ MOPS buffer ( $\mathrm{pH} \mathrm{6.5)}$ ), sonicated for $90 \mathrm{sec}(20 \mathrm{kHz}$; output power $50 \mathrm{~W})$, and diluted with the buffer. Aliquots $(10-50 \mu \mathrm{L})$ of these diluted samples were then used for direct cell counting. Direct total and viable bacterial counts were measured by epifluorescence microscopy with ethidium bromide staining (EtBr) or SYBR Green I and with a Molecular Probes LIVE/DEAD BacLight Viability kit (Invitogen, Carlsbad, CA), respectively, as described $(26,47)$. Stained specimens were observed under an Olympus BX-50 epifluorescence microscope equipped with an Olympus model DP70 CCD camera. The number of stained cells was counted using the image analysis program WINROOF (Flovel, Tachikawa, Japan).

\section{CTC + cell counting}

SCM samples were prepared as described above for total cell counting. Metabolically active cells were stained with the fluorescent redox dye CTC according to a previously described protocol (48) with minor modifications. The CTC reaction mixture contained $800 \mu \mathrm{L}$ of SCM suspension in $50 \mathrm{mM}$ MOPS buffer (pH 6.5), $1 \mathrm{mM}$ CTC (Sigma-Aldrich, St. Louis, Mo), $25 \mathrm{mM}$ Meldla's Blue

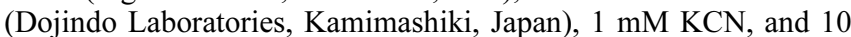
$\mu \mathrm{L}$ of a substrate mixture $(5 \%$ peptone $[\mathrm{w} / \mathrm{v}], 5 \%$ yeast extract $[\mathrm{w} / \mathrm{v}]$ and $2 \%$ glucose $[\mathrm{w} / \mathrm{v}]$ ) in a total of $1.0 \mathrm{~mL}$ in $1.5-\mathrm{mL}$ Eppendorf microtubes. The reaction mixture was incubated in a water bath at $30^{\circ} \mathrm{C}$ for $4 \mathrm{~h}$ with shaking. All these procedures were done in darkness. For microscopic detection, $5 \mu \mathrm{L}$ of the reaction mixture was spotted on a slide glass, fixed by drying at $30^{\circ} \mathrm{C}$ for $5 \mathrm{~min}$ in darkness, and counter-stained for $5 \mathrm{~min}$ with $10 \mu \mathrm{L}$ of a $1 / 10^{4}$-diluted solution of SYBR Green I (Invitogen). Among CTC + bacteria, gram-positive bacteria were detected by post-extracting with acetone (47). CTC+ cell counts were obtained under an Olympus epifluorescence microscope as described for total cell counting.

\section{Flow cytometry and cell sorting}

The quantification and sorting of CTC-stained cells was performed using an EPICS ALTRA flow cytometer (BeckmanCoulter, Miami, FL) equipped with an air-cooled $15 \mathrm{~mW}$ argon laser operating at $488 \mathrm{~nm}$. The emission of the two fluorochromes was recorded through specific band pass filters; $525 \pm 15 \mathrm{~nm}$ for
SYBR Green I and $615 \pm 20 \mathrm{~nm}$ for CTC formazan. An appropriate discriminator was set in the forward scatter mode to exclude small debris and cell fragments. Data on 10,000 cells were recorded and analyzed using EXPO 32 MultiComp software (BeckmannCoulter). In sorting, the number and amplitude of vibrations of the flow cell were $17.7 \mathrm{kHz}$ and $30 \%$, respectively, and a total of 40,000 cells possibly stained with CTC were collected. Epifluorescent microscopy showed that $76 \%$ and more of the cells thus collected under these sorting conditions were actually CTC + cells.

\section{$16 S$ rRNA gene-targeted PCR-DGGE}

DNA was extracted from SCM samples by the method of Zhou et al. (49) with minor modifications as described previously (23). The variable region V3 of bacterial 16S rRNA genes, corresponding to positions 341-534 in the Escherichia coli 16S rRNA (3), was PCRamplified using the forward primer 357f (5'-CCTACGGGAGGCAGCAG-3') with a GC-clamp on the 5' terminus and the reverse primer 517r (5'-ATTACCGCGGCTGCTGG-3') as described by Muyzer et al. (22). Amplification was performed using an AmpliTaq Gold Taq DNA polymerase kit (Applied Biosystems, Foster City, CA) and a Takara Thermal Cycler (Takara Bio, Otsu, Japan). The PCR profile was $10 \mathrm{~min}$ for activating the polymerase at $94^{\circ} \mathrm{C}$ and then 25 or 35 cycles of $1 \mathrm{~min}$ at $94^{\circ} \mathrm{C}, 1 \mathrm{~min}$ at $53^{\circ} \mathrm{C}$, and $1 \mathrm{~min}$ at $72^{\circ} \mathrm{C}$, and finally $5 \mathrm{~min}$ of extension at $72^{\circ} \mathrm{C}$. The PCR products were checked by agarose gel electrophoresis and staining with ethidium bromide. The amplicons were purified with a MicroSpin S-HR400 Column (Amersham Biosciences, Piscataway, NJ) according to the manufacture's recommendations. DGGE was performed in a $10 \%(\mathrm{w} / \mathrm{v})$ polyacrylamide gel at $200 \mathrm{~V}$ for $3.5 \mathrm{~h}$ using a Bio-Rad DCode ${ }^{\mathrm{TM}}$ system (Bio-Rad, Hercules, CA). The gel gradient used for separation was $40-60 \%$. After electrophoresis, the gel was stained with SYBR Green I for 30 min following the manufacturer's instructions and observed with a TOYOBO FAS-III min+ DS-30 transilluminator (Toyobo, Tokyo, Japan).

\section{Sequencing and phylogenetic analysis}

Major DGGE fragments were cut from the gel, purified using a Geneclean Spin kit (Bio 101, Vista, CA), and subcloned with a pTBlue Perfectly Blunt cloning kit (Novagen, Madison, WI) according to the manufacturer's instructions. Transformation of $E$. coli competent cells was carried out by following a standard manual of molecular cloning (36). Plasmid DNA was isolated and purified by using Wizard Minipreps (Promega) as instructed by the manufacturer. The nucleotide sequence of DNA was determined with a cycle sequencing kit and an automated DNA sequencer as described previously (18). We sequenced at least 3 clones per DGGE fragment, and confirmed all these clones to have the same sequence. Sequence data were compiled with the GENETYX-MAC program (Genetyx, Tokyo, Japan) and subjected to a BLAST homology search (1) and the matching of sequences in the Ribosomal Database Project (RDP) II (6) to ascertain the phylogenetic position of isolates. The multiple alignment of sequence data, calculation of the corrected evolutionary distance (20), and construction of a neighbor-joining phylogenetic tree (35) were performed using the CLUSTAL W program ver. 1.83 (42). The topology of the tree was evaluated by bootstrapping with 1,000 trials (10).

\section{Nucleotide database accession numbers}

The 16S rRNA gene sequences reported in this study have been deposited under DDBJ accession numbers $\mathrm{AB} 474788$ to AB474793.

\section{Results}

\section{Changes in physico-chemical parameters}

The mass reduction rate during the overall period of FBC operation was $94 \%$, indicating a good waste-reduction efficiency. The core temperature of the reactor varied between 
33 and $43^{\circ} \mathrm{C}$ due to self-heating (Fig. 1a). The pH of SCM decreased to 5.7 at the early stage and then increased gradually during the overall period, reaching around 9.5 after 2 months of operation (Fig. 1b). The moisture content was over $50 \%$ for 10 days from the start of waste delivery but became stable at 30 to $40 \%$ during the latter half of operation (Fig. 1c). The $a_{\mathrm{w}}$ decreased linearly with time and reached a value of between 0.94 and 0.95 at the end of operation (Fig. 1d). In view of the changes in temperature, moisture, and $\mathrm{pH}$, the reactor could be regarded as reaching the acclimated phase after 1 month of operation. These physicochemical changes are typical of the mesophilic FBC process during the start-up period as described previously $(24,41)$.

\section{Succession of total, viable, and CTC + counts}

The total bacterial count increased sharply from the start of waste loading and reached an order of $10^{11}$ cells $\mathrm{g}^{-1}$ (dry wt) of SCM on day 7 of operation (Table 1). Thereafter, the total count became stable at between $2.9 \times 10^{11}$ and $5.0 \times 10^{11}$ $\mathrm{g}^{-1}$ (dry wt). The direct viable count measured with a LIVE/ DEAD BacLight kit accounted for $75-89 \%$ of the total count during the first week and $49-66 \%$ of the total count thereafter.

The CTC+ count as measured by epifluorescent microscopy was $75-84 \%$ of the total count during the first week of operation but dropped sharply to $19-35 \%$ under steady-state conditions (on days 28-56) (Table 1). A decrease in the proportion of $\mathrm{CTC}+$ populations with operation time was also found by FCM (Table 1 and Fig. 1). FCM measurements gave higher $\mathrm{CTC}+$ counts than did the microscopic analysis. This was due to the overestimated CTC + counts obtained by FCM, as microscopic checking of FCM-sorted CTC+ cells revealed that $76-92 \%$ of all the cells collected were actually $\mathrm{CTC}+$. There was a highly positive correlation between the microscopic count and the corrected FCM count $\left(r^{2}=0.9476\right)$.

Most of the CTC+ cells detected during the first week $(>70 \%)$ were decolorized by treatment with acetone (data not shown). On the other hand, only $12-30 \%$ of the CTC+ cells found at the steady-state stage were decolorized by acetone treatment. This suggested that most of the metabolically active bacteria at the steady-state stage were gram positive,
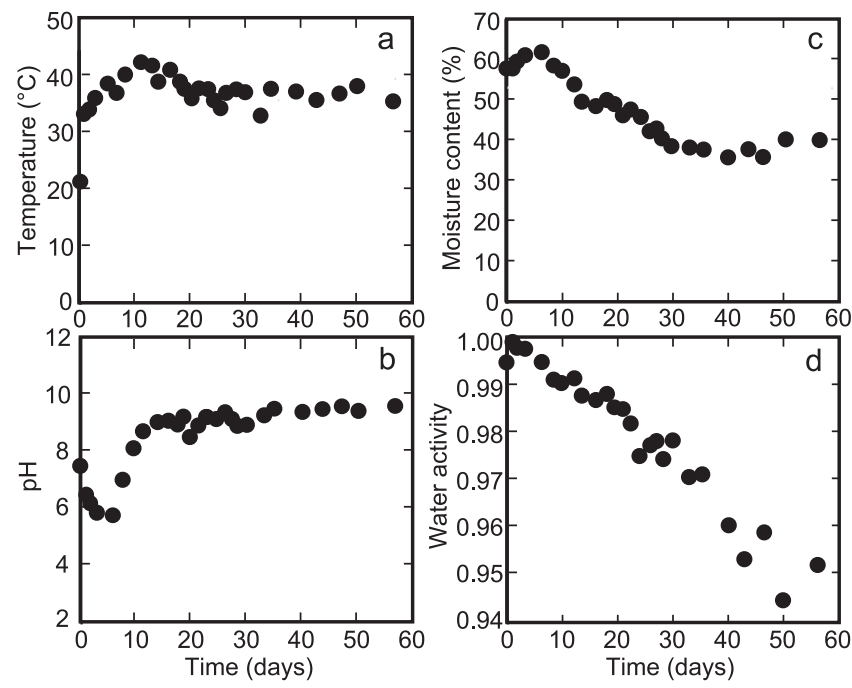

Fig. 1. Changes in physico-chemical parameters during fed-batch composting of household organic waste. (a) core temperature; (b) $\mathrm{pH}$; (c) moisture content; (d) water activity $\left(a_{\mathrm{w}}\right)$.

as it has been shown that $\mathrm{CTC}+$ gram-positive bacteria are not decolorized with acetone (47).

\section{Succession of quinone profiles}

The total quinone content of SCM increased sharply during the first 2 weeks of operation, and thereafter became stable at between 170 and $240 \mathrm{nmol} \mathrm{g}^{-1}$ (dry wt) (Table 1). Assuming that $1 \mathrm{nmol}$ of total respiratory quinones corresponds to $2.1 \times 10^{9}$ cells of bacteria in soil and compost (16), the total counts predicted based on the quinone contents are $3.6-5.0 \times 10^{11}$ cells $\mathrm{g}^{-1}$ under steady-state conditions. These values are similar to the direct total counts obtained by epifluorescent microscopy. Early in the FBC process (on days 1-14), ubiquinones predominated (59-85 $\mathrm{mol} \%$ of the total content). With time, however, the amount of ubiquinones decreased gradually with a concomitant increase in the amount of partially saturated menaquinones. At the end of operation, ubiquinones and partially saturated menaquinones accounted for 14 and $57 \mathrm{~mol} \%$ of the total content, respec-

Table 1. Comparative direct total, viable, and CTC+ counts of bacteria and quinone contents in the $\mathrm{FBC}$ reactor

\begin{tabular}{|c|c|c|c|c|c|c|c|c|}
\hline \multirow{3}{*}{$\begin{array}{l}\text { Sample } \\
\text { on day: }\end{array}$} & \multirow{3}{*}{$\begin{array}{c}\text { Direct total count } \\
\left(\times 10^{11} \text { cells } \mathrm{g}^{-1} \text { dry wt }\right)^{\mathrm{a}}\end{array}$} & \multirow{3}{*}{$\begin{array}{l}\text { Direct viable count } \\
\quad(\% \text { of total })^{\mathrm{b}}\end{array}$} & \multicolumn{3}{|c|}{ CTC + count $(\%$ of total $)$} & \multicolumn{3}{|c|}{ Quinone content } \\
\hline & & & \multirow{2}{*}{$\begin{array}{l}\text { Epifluorescence } \\
\text { microscopy }\end{array}$} & \multirow{2}{*}{$\mathrm{FCM}$} & \multirow{2}{*}{$\begin{array}{c}\text { Total content } \\
\text { (nmol g }{ }^{-1} \text { dry wt) }\end{array}$} & \multicolumn{3}{|c|}{ Mol\% } \\
\hline & & & & & & Q- $n$ & MK- $n$ & $\mathrm{MK}-n\left(\mathrm{H}_{x}\right)$ \\
\hline 3 & 0.25 & $75 \pm 5$ & $75 \pm 3$ & nd & 11 & 85 & 14 & 1 \\
\hline 5 & 0.69 & $88 \pm 2$ & $84 \pm 3$ & nd & 40 & 70 & 28 & 2 \\
\hline 7 & 1.0 & $89 \pm 3$ & $82 \pm 2$ & $88(81)^{\mathrm{e}}$ & 69 & 68 & 28 & 4 \\
\hline 14 & 2.9 & $66 \pm 5$ & $40 \pm 3$ & $69(53)$ & 170 & 59 & 30 & 11 \\
\hline 28 & 5.0 & $57 \pm 6$ & $35 \pm 5$ & $68(52)$ & 240 & 36 & 34 & 30 \\
\hline 42 & 3.9 & $52 \pm 4$ & $26 \pm 4$ & $46(37)$ & 230 & 21 & 31 & 48 \\
\hline 56 & 4.0 & $49 \pm 4$ & $19 \pm 6$ & $34(26)$ & 240 & 14 & 29 & 57 \\
\hline
\end{tabular}

a SYBR Green I count by epifluorescence microscopy

${ }^{b}$ LIVE/DEAD BacLight count (average \pm standard deviation of three determinations).

${ }^{c}$ Average \pm standard deviation of three determinations.

${ }^{\mathrm{d}}$ nd, not determined.

e Figures in parentheses indicate corrected values based on the microscopic analysis of FCM-sorted cells. 


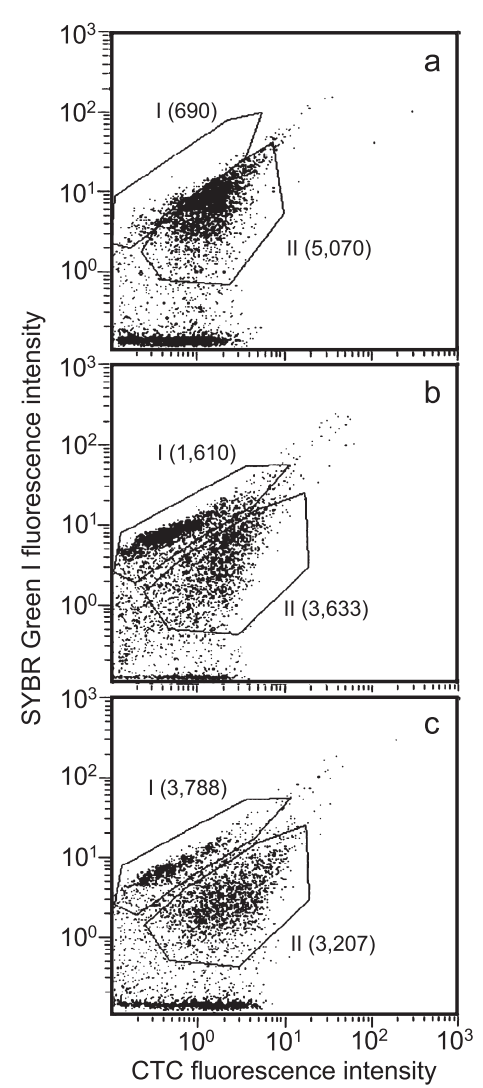

Fig. 2. FCM analyses of CTC+ bacteria in the reactor on days 7 (a), 14 (b), and 42 (c). Assemblies of particles surrounded by lines I and II indicate cells stained only with SYBR Green I and CTC+ cells, respectively, and figures in parentheses denote the number of cells measured. Cells in area II were sorted and subjected to PCR-DGGE analyses as the $\mathrm{CTC}+$ fraction.

tively. The most abundant quinone species detected under steady-state conditions were $\mathrm{MK}-8\left(\mathrm{H}_{4}\right)$ (25 mol\%). Other quinone homologs accounting for more than $5 \mathrm{~mol} \%$ at the end of operation were Q-10 (11\%), MK-7 (11\%), MK-8 $(9 \%)$, MK- $9\left(\mathrm{H}_{4}\right)(6 \%)$, MK- $9\left(\mathrm{H}_{2}\right)(5 \%)$, and MK-9 $\left(\mathrm{H}_{8}\right)(5 \%)$. These data indicate that a population shift from ubiquinonecontaining members of the Proteobacteria (i.e., Alpha-, Beta-, and Gammaproteobacteria) to the Actinobacteria took place during the FBC operation, well consistent with previous reports $(17,23,25,41)$.

\section{PCR-DGGE analyses}

$\mathrm{CTC}+$ cells collected from the FBC reactor by FCM sorting were subjected to $16 \mathrm{~S}$ rRNA gene-targeted PCR-DGGE analyses in comparison with the total bacterial cells. Although amplification with 25 cycles rather than 35 cycles might be better to detect DGGE clones representing the bacterial composition, the former PCR resulted in the production of faint PCR signals and markedly fewer numbers of DGGE bands. Therefore, only results of PCR with 35 cycles are shown herein. As shown in Fig. 3, a drastic change in DGGE patterns of both total and CTC+ populations was observed during the first 3 weeks of operation. Thereafter, the PCRDGGE pattern became relatively stable in the two fractions. It is worth noting that the total and CTC+ cell fractions occasionally gave different PCR-DGGE patterns from each other, as was the case on days 3, 14, and 56 (see also Fig. 4).

A total of 20 major DGGE fragments were cut from the gel, subcloned, and then sequenced. The results of a BLAST homology search and a RDP-II sequence match analysis of the 16S rRNA gene sequences determined are shown in Table 2. Also, a neighbor-joining phylogenetic tree for these clones and their phylogenetic relatives retrieved from databases is shown in Fig. 4. The DGGE clones analyzed were classified into 9 different phylogenetic groups that corresponded to established species or uncultured bacteria of the phyla Actinobacteria, Bacteroidetes, Firmicutes, and Proteobacteria (the classes Alphaproteobacteria and Gammaproteobacteria). These results showed that the proteobacterial clones were abundant early in the process, whereas actinobacterial clones were detected at the steady-state stage (on day 21 and thereafter). This community change was similarly found in both CTC+ and total population fractions.

\section{Discussion}

The detection of viable and metabolically active populations in microbial communities in terms of quantity and quality is an important task in research on microbial ecology. Approaches to this research include microradioautographyfluorescence in situ hybridization $(29,45)$, stable isotope probing $(27,28,34)$, and staining with viability-probing fluorescent dyes such as CTC (19). Since the CTC staining method is rapid and simple to perform and requires no expensive instruments or a restricted experimental area, it is widely used for the detection of metabolically active microorganisms at a single-cell resolution. However, the method itself gives no information about the quality of target organisms in terms of phylogeny and taxonomy, although a modified version with acetone treatment can roughly estimate the proportion of gram-positive and gram-negative bacteria. To address this issue, we combined the use of CTC staining, FCM, and cell sorting followed by PCR-DGGE as reported herein. Before this study, there had been few reports on the phylogenetic characterization of CTC+ populations as estimated with a combination of FCM sorting and PCR-DGGE profiling (2). To our knowledge, the present study is the first to apply this approach to compost microbial communities.

This study revealed that the proportion of CTC + populations to the total bacterial population was high early in the FBC process but decreased with time. This decrease is not due to technical reasons but reflects an actual reduction in numbers of metabolically active bacteria, because the proportion of the total viable count as measured with the LIVE/ DEAD Baclight kit decreased with operation time. Previous studies have shown that the culturability of microorganisms in FBC reactors at the steady-state stage is high, as the place count of aerobic heterotrophic bacteria accounts for approximately $50 \%$ of the direct total count $(26,41)$. On comparing this with the direct viable count and the CTC+ count recorded in this study, it is likely that most of the viable bacteria present in the $\mathrm{FBC}$ reactor under steady-state conditions are cultivable on ordinary culture media, although why the CTC+ count might be occasionally lower than the plate count is not known. One major determinant of the increase in the proportion of metabolically inactive or dead bacteria at the 


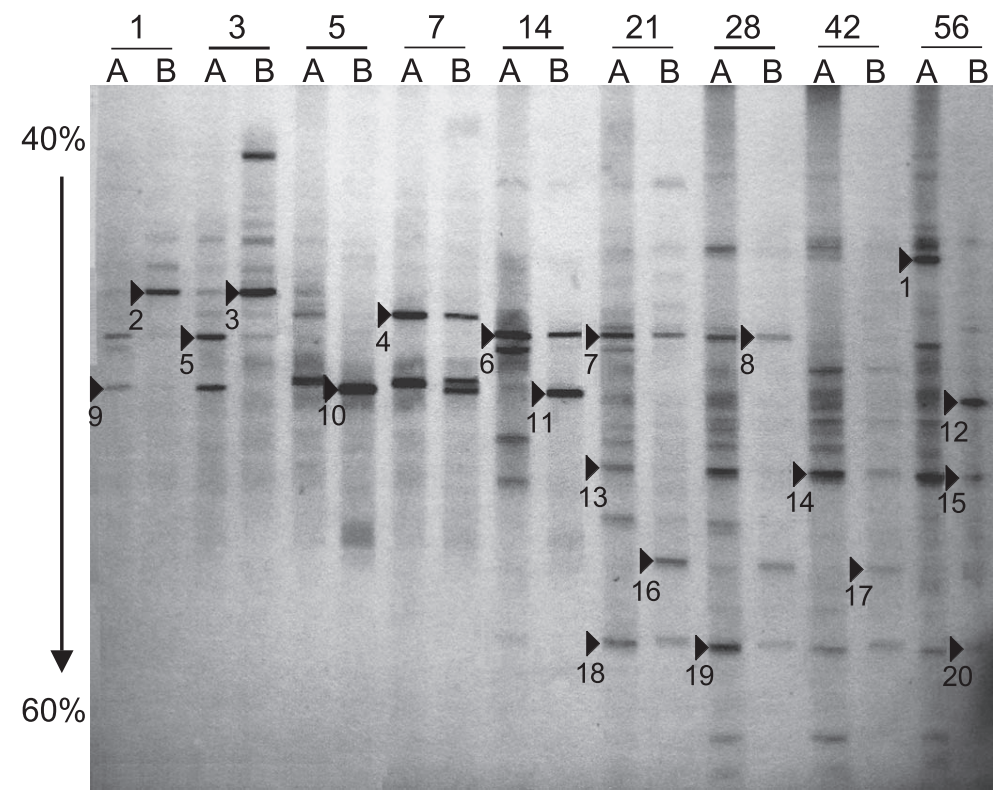

Fig. 3. 16S rRNA-targeted PCR-DGGE analysis of the total bacterial community (lane A) and the CTC+ bacterial community (lane B) in the FBC reactor. A negative image of DGGE patterns (detected by staining with SYBR Green I) on days 1 to 56 is shown. The days on which SCM samples were taken are shown on the top of the DGGE image. The DGGE bands shown by arrows with figures are those subjected to sequence analyses.

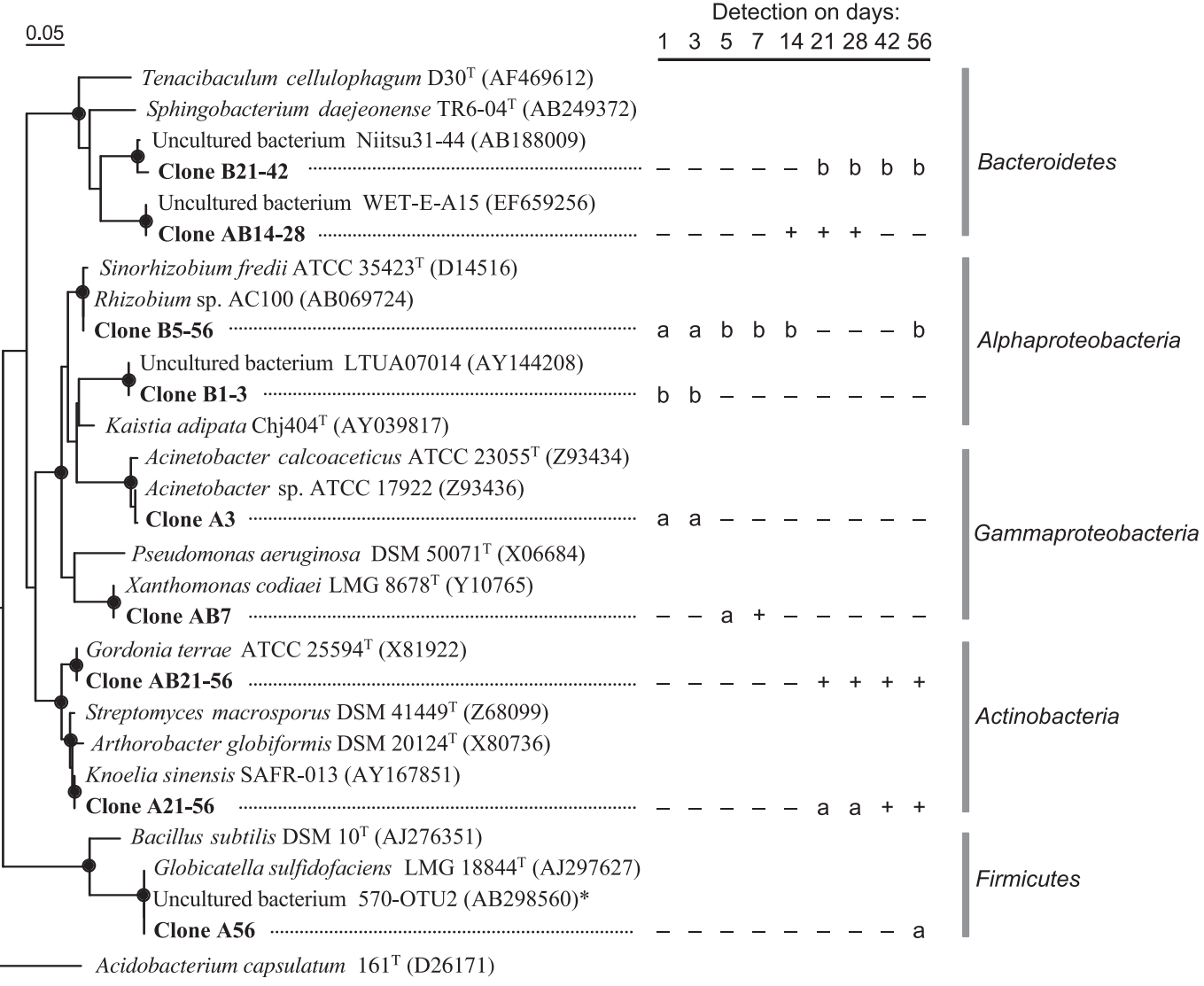

Fig. 4. Neighbor-joining distance matrix tree of 16S rRNA gene sequences of the DGGE clones detected in the FBC reactor and their phylogenetic relatives. The accession numbers for the sequences are shown behind organism names. Acidobacterium capsulatum strain $161^{\mathrm{T}}$ (D26171) was used as an outgroup to root the tree. Scale bar $=5 \%$ nucleotide substitution rate $\left(K_{\text {nuc }}\right)$. Nodes showing a bootstrap value of more than $80 \%$ (1,000 resamplings) are shown by solid circles. The days on which the DGGE clones were detected are shown on the right side: a, detected in the total bacterial fraction; $b$, detected only in the CTC+ fraction; +, detected in both fractions; -, not detected. 
Table 2. Phylogenetic identification of PCR-DGGE clones from the reactor

\begin{tabular}{|c|c|c|c|c|c|c|}
\hline \multirow[b]{2}{*}{$\begin{array}{l}\text { DGGE } \\
\text { band }\end{array}$} & \multirow[b]{2}{*}{$\begin{array}{l}\text { Clone } \\
\text { name }\end{array}$} & \multicolumn{2}{|l|}{ BLAST match } & \multicolumn{2}{|l|}{ RDP-II match with type strain } & \multirow[b]{2}{*}{ Phylum/class } \\
\hline & & $\begin{array}{c}\text { Organism } \\
\text { (accession number) }\end{array}$ & $\begin{array}{c}\% \\
\text { Similarity }\end{array}$ & $\begin{array}{c}\text { Organism } \\
\text { (accession number) }\end{array}$ & $\begin{array}{c}\% \\
\text { Similarity }\end{array}$ & \\
\hline 1 & A56 & $\begin{array}{l}\text { Uncultured compost bacterium } \\
\text { 570-OTU2 (AJ297627) }\end{array}$ & 100 & $\begin{array}{l}\text { Globicatella sulfidifaciens LMG } \\
18844^{\mathrm{T}} \text { (AJ297627) }\end{array}$ & 100 & Firmicutes \\
\hline $2 / 3$ & B1-3 & $\begin{array}{l}\text { Uncultured alphaproteobacterium } \\
\text { LTUA07014 (AY144208) }\end{array}$ & 100 & $\begin{array}{l}\text { Kaistia adipata } \text { Chj } 404^{\mathrm{T}} \\
\text { (AY039817) }\end{array}$ & 91.7 & Alphaproteobacteria \\
\hline 4 & AB7 & $\begin{array}{l}\text { Xanthomonas codiaei LMG } 8678^{\mathrm{T}} \\
(\mathrm{Y} 10765)\end{array}$ & 100 & $\begin{array}{l}\text { Xanthomonas codiaei LMG } 8678^{\mathrm{T}} \\
\text { (Y10765) }\end{array}$ & 100 & Gammaproteobacteria \\
\hline 5 & A3 & $\begin{array}{l}\text { Acinetobacter sp. ATCC } 17922 \\
\text { (Z93436) }\end{array}$ & 99.5 & $\begin{array}{l}\text { Acinetobacter calcoaceticus ATCC } \\
23055^{\mathrm{T}}(\mathrm{Z} 93434)\end{array}$ & 97.5 & Gammaproteobacteria \\
\hline $6 / 7 / 8$ & AB14-28 & $\begin{array}{l}\text { Uncultured bacterium WET-E-A15 } \\
\text { (EF659256) }\end{array}$ & 100 & $\begin{array}{l}\text { Tenacibaculum skagerrakense } \mathrm{D} 30^{\mathrm{T}} \\
\text { (AF469612) }\end{array}$ & 88.4 & Bacteroidetes \\
\hline $9 / 10 / 11 / 12$ & B5-56 & Rhizobium sp. AC100 (AB069724) & 100 & $\begin{array}{l}\text { Sinorhizobium fredii ATCC } 35423^{\mathrm{T}} \\
\text { (X67231) }\end{array}$ & 99.4 & Alphaproteobacteria \\
\hline $13 / 14 / 15$ & A21-56 & $\begin{array}{l}\text { Knoellia sinensis SAFR-013 } \\
\text { (AY167851) }\end{array}$ & 100 & $\begin{array}{l}\text { Sterptomyces macrosporus DSM } \\
41449^{\mathrm{T}}(\mathrm{Z} 68099)\end{array}$ & 99.4 & Actinobacteria \\
\hline $16 / 17$ & B21-42 & $\begin{array}{l}\text { Uncultured bacterium Niitsu31-44 } \\
\text { (AB188009) }\end{array}$ & 98.4 & $\begin{array}{l}\text { Sphingobacterium daejeonense } \\
\text { TR6-04T (AB249372) }\end{array}$ & 87.8 & Bacteroidetes \\
\hline $18 / 19 / 20$ & AB21-56 & $\begin{array}{l}\text { Gordonia terrae ATCC } 25594^{\mathrm{T}} \\
\text { (X81922) }\end{array}$ & 100 & $\begin{array}{l}\text { Gordonia terrae ATCC } 25594^{\mathrm{T}} \\
\text { (X81922) }\end{array}$ & 100 & Actinobacteria \\
\hline
\end{tabular}

fully acclimated stage may be the availability of water.

Consistent with previous papers $(17,23,25,41)$, this study has shown that a drastic population shift from ubiquinonecontaining Proteobacteria (especially Alpha- and Gammaproteobacteria) to the Actinobacteria takes place during the start-up operation of the mesophilic FBC process. Takebayashi et al. (41) have reported that aw is one of the most important determinants of this population change. They reported that the isolates of Actinobacteria were much more tolerant of low levels of aw than those of Proteobacteria, and Firmicutes isolates exhibited intermediate tolerance (41). In this study, quinone profiling and PCR-DGGE profiling of the total and CTC+ populations demonstrated a population change concomitant with a decrease in $a_{\mathrm{w}}$ during the overall period of operation. These observations suggest that the phylogenetic composition of metabolically active bacteria in the FBC process also changes from the Proteobacteria to Actinobacteria during the overall period of operation. In the conventional batch composting process, actinobacterial populations become more abundant during the cooling and maturation phase $(11,33,43)$, in which the availability of certain nutrients (e.g., lignin and humic acid) may be an important determinant of population dynamics. The potential significance of such specific nutrients in addition to $a_{\mathrm{w}}$ as factors affecting population changes in the FBC should be elucidated in further study.

It is worth noting that the CTC + and total populations occasionally gave different PCR-DGGE patterns to each other. This suggests that metabolically active bacteria as measured by CTC staining are not always predominant in the FBC process, although the overall population shift from ubiquinone-containing Proteobacteria to the Actinobacteria may take place not only in the total community but also in CTC+ populations. Since the FBC reactor is seeded periodically with large populations of microorganisms on the loading of fresh biowaste, it may be that these exogenous microbes temporally grow faster or have higher levels of activity than the predominant bacteria in the reactor. For example, this may be the case in the detection of an alphaproteobacterial clone (B5-56) on day 56 (Figs. 3 and 4). In view that Q-10, a quinone species specific to the Alphaproteobacteria and some fungi, still accounted for more than $10 \%$ of the total quinone content at the end of FBC operation, however, one can not exclude the possibility that these ubiquinone-containing microorganisms play primary roles in the degradation of biowaste under steady-state conditions.

In conclusion, the combined use of CTC staining and FCM sorting followed by PCR-DGGE profiling or other molecular approaches has great promise for the rapid detection and phylogenetic identification of metabolically active bacteria in a microbial community. The overall procedure of this method can be completed within a couple of days. Substrate-specific CTC staining and FCM sorting may give more useful information about relationships between the kind of microorganisms involved and substrate utilization patterns. The method presented here can be applied not only to studies of compost microbial communities but also to research on microbial ecology in various environments.

\section{Acknowledgements}

We are grateful to Yuji Kanosue for technical assistance. This study was carried out as part of the 21st Century COE Program "Ecological Engineering and Homeostatic Human Activities" supported by the Ministry of Education, Culture, Sports, Science and Technology, Japan.

\section{References}

1. Altschul, S.F., T.L. Madden, A.A. Schaffer, J. Zhang, Z. Zhang, W. Miller, and D.J. Lipman. 1997. Gapped BLAST and PSI-BLAST: A new generation of protein database search programs. Nucleic Acids Res. 25:3389-3402.

2. Bernard, L., C. Courties, C. Duperray, H. Schäfer, G. Muyzer, and P.A. Lebaron. 2001. A new approach to determine the genetic diversity of viable and active bacteria in aquatic ecosystems. Cytometry 43:314-321.

3. Brosius, J., J.L. Palmer, J.P. Kennedy, and H.F. Noller. 1978. Complete nucleotide sequence of a 16S rRNA gene from Escherichia coli. Proc. Natl. Acad. Sci. USA 75:4801-4805.

4. Chen, P.S., and C.S. Li. 2005. Bioaerosol characterization by flow 
cytometry with fluorochrome. J. Environ. Monit. 7:950-959.

5. Choi, J.W., B.F. Sherr, and E.B. Sherr. 1999. Dead or alive? A large fraction of ETS-inactive marine bacterioplancton cells, as assessed by the reduction of CTC, can become ETS-active with incubation and a substrate addition. Aquat. Microb. Ecol. 18:105-115.

6. Cole, J.R., B. Chai, R.J. Farris, Q. Wang, A.S. Kulam-SyedMohideen, D.M. McGarrell, A.M. Bandela, E. Cardenas, G.M Garrity, and J.M. Tiedje. 2007. The ribosomal database project (RDP-II): Introducing myRDP space and quality controlled public data. Nucleic Acids Res. 35 (Database issue):D169-D172.

7. Creach, V., A.C. Baudoux, G. Bertru, and B.L. Rouzic. 2003. Direct estimate of active bacteria: CTC use and limitations. J. Microbiol. Methods 52:19-28.

8. del Giorgio, P.A., Y.T. Prairie, and D.F. Bird. 1997. Coupling between rates of bacterial production and the abundance of metabolically active bacteria in lakes, enumeration using CTC reduction and flow cytometry. Microb. Ecol. 34:144-154

9. del Giorgio, P.A., and G. Scarborough. 1995. Increase in the proportion of metabolically active bacteria along gradients of enrichmen in freshwater and marine plankton; implications for estimates of bacterial growth and production. J. Plankton Res. 17:1905-1924.

10. Felsenstein, J. 1985. Confidence limits on phylogenies: an approach using the bootstrap. Evolution 39:783-791.

11. Forgarty, A.M., and O.H. Tuovinen. 1991. Microbiological degradation of pesticides in yard waste composting. Microbiol. Rev. 55:225233.

12. Frederiks, W.M., J. van Marle, C. van Oven, B. Comin-Anduix, and M. Cascante. 2006. Improved localization of glucose-6-phosphate dehydrogenase activity in cells with 5-cyano-2,3-ditolyl-tetrazolium chloride as fluorescent redox dye reveals its cell cycle-dependen regulation. J. Histochem. Cytochem. 54:47-52.

13. Gruden, C.L., A. Khijniak, and P. Adriaens. 2003. Activity assessment of microorganisms eluted from sediments using 5-cyano-2,3 ditolyl tetrazolium chloride: A quantitative comparison of flow cytometry to epifluorescent microscopy. J. Microbiol. Methods. 55:865-874

14. Hatzinger, P.B., P. Palmer, R.L. Smith, C.T. Penarrieta, and T. Yoshinari. 2003. Applicability of tetrazolium salts for the measurement of respiratory activity and viability of groundwater bacteria. J. Microbiol. Methods 52:47-58.

15. Hiraishi, A. 1999. Isoprenoid quinines as biomarkers of microbia populations in the environment. J. Biosci. Bioeng. 88:449-460.

16. Hiraishi, A., M. Iwasaki, T. Kawagishi, N. Yoshida, T. Narihiro, and K. Kato. 2003. Significance of lipoquinones as quantitative biomarkers of bacterial populations in the environment. Microbes Environ. 18:89-93.

17. Hiraishi, A., T. Narihiro, and Y. Yamanaka. 2003. Microbial community dynamics during start-up operation of flowerpot-using fed-batch reactors for composting of household biowaste. Environ. Microbiol. 5:765-776.

18. Hisada, T., K. Okamura, and A. Hiraishi. 2007. Isolation and characterization of phototrophic purple nonsulfur bacteria from Chloroflexus and cyanobacterial mats in hot springs. Microbes Environ. 22:405-411.

19. Joux, F., and P. Lebaron. 2000. Use of fluorescent probes to assess physiological functions of bacteria at single-cell level. Microbes Infect. 2:1523-1535.

20. Kimura, M. 1980. A simple method for estimating evolutionary rates of base substitution through comparative studies of nucleotide sequences. J. Mol. Evol. 16:111-120.

21. Longnecker, K., B.F. Sherr, and E.B. Sherr. 2005. Activity and phylogenetic diversity of bacterial cells with high and low nucleic acid content and electron transport system activity in an upwelling ecosystem. Appl. Environ. Microbiol. 71:7737-7749.

22. Muyzer, G., E.C. De Waal, and A.G. Uitterlinden. 1993. Profiling of complex microbial populations by denaturing gradient gel electrophoresis analysis of polymerase chain reaction-amplified genes coding for 16S rRNA. Appl. Environ. Microbiol. 59:695-700.

23. Narihiro, T., T. Abe, Y. Yamanaka, and A. Hiraishi. 2004. Microbial population dynamics during fed-batch operation of commercially available garbage composters. Appl. Microbiol. Biotechnol. 65:488495.

24. Narihiro, T., and A. Hiraishi. 2005. Microbiology of fed-batch composting. Microbes Environ. 20:1-13.

25. Narihiro, T., S. Takebayashi, and A. Hiraishi. 2004. Activity and phylogenetic composition of proteolytic bacteria in mesophilic fedbatch garbage composters. Microbes Environ. 19:292-300.

26. Narihiro, T., Y. Yamanaka, and A. Hiraishi. 2003. High culturability of bacteria in commercially available personal composters for fedbatch treatment of household biowaste. Microbes Environ. 18:94-99.

27. Neufeld, J.D., M.G. Dumont, J. Vohra, and J.C. Murrell. 2007. Meth- odological considerations for the use of stable isotope probing in microbial ecology. Microb. Ecol. 53:435-442.

28. Neufeld, J.D., M. Wagner, and J.C. Murrell. 2007. Who eats what where and when? Isotope-labelling experiments are coming of age. ISME J. 1:103-110.

29. Okabe, S., T. Kindaichi, and T. Ito. 2004. MAR-FISH-An ecophysiological approach to link phylogenetic affiliation and in situ metabolic activity of microorganisms at a single-cell resolution. Microbes Environ. 19:83-98.

30. Proctor, L.M., and A.C. Souza. 2001. Method for enumeration of 5-cyano-2,3-ditolyl tetrazolium chloride (CTC)-active cells and cell-specific CTC activity of benthic bacteria in river, estuarine and coastal sediments. J. Microbiol. Methods 43:213-222.

31. Pyle, B.H., S.C. Broadway, and G.A. McFeters. 1995. Factors affecting the determination of respiratory activity on the basis of cyanoditolyl tetrazolium chloride reduction with membrane filtration. Appl. Environ. Microbiol. 61:4304-4309.

32. Rodriguez, G.G., D. Phipps, K. Ishiguro, and H.F. Ridgway. 1992 Use of a fluorescent redox probe for direct visualization of actively respiring bacteria. Appl. Environ. Microbiol. 58:1801-1808.

33. Ryckeboer, J., J. Mergaert, J. Coosemans, K. Deprins, and J. Swings. 2003. Microbiological aspects of biowaste during composting in a monitored compost bin. J. Appl. Microbiol. 94:127-137.

34. Saito, T., S. Ishii, S. Otsuka, M. Nishiyama, and K. Senoo. 2008. Identification of novel Betaproteobacteria in a succinate-assimilating population in denitrifying rice paddy soil by using stable isotope probing. Microbes Environ. 23:192-200.

35. Saitou, N., and M. Nei. 1987. The neighbor-joining method: A new method for reconstructing phylogenetic trees. Mol. Biol. Evol. 4:406425.

36. Sambrook, J., E.F. Fritsch, and T. Manatais. 1989. Molecular Cloning: A Laboratory Manual, 2nd ed. Cold Spring Harbor Laboratory Press, Cold Spring Harbor.

37. Schaule, G., H.C. Flemming, and H.F. Ridgway. 1993. Use of 5cyano-2,3-ditolyl tetrazolium chloride for quantifying planktonic and sessile respiring bacteria in drinking water. Appl. Environ. Microbiol. 59:3850-3857.

38. Servais, P., H. Agogue, C. Courties, F. Joux, and P. Lebaron. 2001 Are the actively respiring cells (CTC + ) those responsible for bacterial production in aquatic environments? FEMS Microbiol. Ecol. 35:171179.

39. Sherr, B.F. P del Giorgio, and E.B. Sherr. 1999. Estimating abundance and single-cell characteristics of respiring bacteria via the redox dye CTC. Aquat. Microb. Ecol. 18:117-131.

40. Sieracki, M.E., T.L. Cucci, and J. Nicinski. 1999. Flow cytometric analysis of 5-cyano-2,3-ditolyl tetrazolium chloride activity of marine bacterioplankton in dilution cultures. Appl. Environ. Microbiol 65:2409-2417

41. Takebayashi, S., T. Narihiro, Y. Fujii, and A. Hiraishi. 2007. Water availability is a critical determinant of a population shift from Proteobacteria to Actinobacteria during start-up operation of mesophilic fed-batch composting. Microbes Environ. 22:279-289.

42. Thompson, J.D. D.G. Higgins, and T.J. Gibson 1994 CLUSTAL W: Improving the sensitivity of progressive multiple sequence alignment through sequencing weighting, position-specific gap penalties and weight matrix choice. Nucleic Acids Res. 22:4673-4680.

43. Tuomela, M., M. Vikman, A. Hatakka, and M. Itävaara, 2000. Biodegradation of lignin in a compost environment: A review. Bioresour. Technol. 72:169-183

44. Ullich, S., B. Karrasch, H.G. Hoppe, K. Jeskuke, and M. Mehrens. 1996. Toxic effects on bacterial metabolism of the redox dye 5-cyano 2,3-ditolyl tetrazolium chloride. Appl. Environ. Microbiol. 62:45874593

45. Wagner, M., P.H. Nielsen, A. Loy, J.L. Nielsen, and H. Daims. 2006 Linking microbial community structure with function: Fluorescence in situ hybridization-microautoradiography and isotope arrays. Curr. Opin. Biotechnol. 17:83-91.

46. Whiteley, A.S., R.I. Griffiths, and M.J. Bailey. 2003. Analysis of the microbial functional diversity within water-stressed soil communities by flow cytometric analysis and CTC + cell sorting. J. Microbiol. Methods. 54:257-267.

47. Yoshida, N., Y. Fujii, and A. Hiraishi. 2006. A modified cyanoditolyl tetrazolium reduction method for differential detection of metabolically active gram-positive and gram-negative bacteria. Microbes Environ. 21:271-277.

48. Yoshida, N., and A. Hiraishi. 2004. An improved redox dye-staining method using 5-cyano-2,3-ditoryl tetrazolium chloride for detection of metabolically active bacteria in activated sludge. Microbes Environ. 19:61-70.

49. Zhou, J., M.A. Bruns, and J.M. Tiedje. 1999. DNA recovery from soils of diverse composition. Appl. Environ. Microbiol. 62:316-322. 